\section{Social and environmental} inequities in dental caries among indigenous population in Brazil: evidence from 2000 to 2007

\author{
Desigualdades socioambientais \\ na ocorrência de cárie dentária \\ na população indígena no Brasil: \\ evidências entre 2000 e 2007
}

\section{Pedro Alves Filho'}

Ricardo Ventura Santos"

Mario Vianna Vettore ${ }^{\text {III }}$

'Secretaria de Estado de Saúde do Rio de Janeiro (SES-RJ) - Rio de Janeiro (RJ), Brazil.

"Escola Nacional de Saúde Pública, Fundação Oswaldo Cruz e Museu Nacional da Universidade Federal do Rio de Janeiro - Rio de Janeiro (RJ), Brazil.

'IIInstituto de Estudos em Saúde Coletiva da Universidade Federal do Rio de Janeiro - Rio de Janeiro (RJ), Brazil.

Corresponding author: Pedro Alves Filho. Secretaria de Estado de Saúde do Rio de Janeiro (SES-RJ) - Rua México, 128, Centro, CEP: 20031-142, Rio de Janeiro, Brasil. E-mail: pafilho@msn.com Conflict of interests: nothing to declare.

\begin{abstract}
This ecological study investigated the association between social and environmental inequities and dental caries among indigenous people in Brazil. Dental caries data were gathered from articles identified from electronic databases for the period between 2000 and 2007 . Independent variables were obtained from the census of Health Information System for Sanitation Indigenous Populations. Multiple linear regression analysis was conducted to test the association between social and environmental characteristics and dental caries (DMFT index) according to the age group. Results were analyzed for 48 indigenous peoples from 19 selected studies. The occurrence of dental caries in particular age groups was inversely associated with the location of villages outside the Amazon region (12, 15 - 19, and 20 - 34 years), availability of electricity (15 - 19 and 20 - 34 years) and proportion of households covered with straw/thatch (20 - 34 years). The presence of schools was statistically associated with higher DMFT averages (15 - 19 and 20 - 34 years). It can be concluded that aspects of location and existing infrastructure in indigenous communities, which are linked to the availability of oral health services, are associated with the occurrence of dental caries in indigenous populations in Brazil.
\end{abstract}

Keywords: Dental caries. Health inequities. Periodontal diseases. Oral health. Health of indigenous people. Dental health services. 


\section{Resumo}

Foi realizado um estudo ecológico para investigar a associação entre desigualdades sociais e ambientais com a cárie dentária em povos indígenas no Brasil. As informações sobre cárie dentária foram extraídas de estudos publicados entre 2000 e 2007 e recuperados em bases bibliográficas. As variáveis independentes foram obtidas a partir dos estudos e de informações disponíveis no Sistema de Informação de Saneamento Básico para Populações Indígenas (SISABI). Análises de regressão linear múltipla foram empregadas para testar a associação entre características socioambientais e cárie dentária (índice CPOD), estratificadas por idade. As informações analisadas derivam de 48 povos indígenas investigados em 19 estudos. A ocorrência da cárie dentária foi inversamente associada à localização de aldeias fora da região da Amazônia Legal (aos 12, 15 - 19 e 20 - 34 anos), eletrificação (aos 15 - 19 e 20 - 34 anos) e proporção de casas com cobertura de palha/sapê (aos 20 - 34 anos). A presença de escola foi estatisticamente associada a maiores médias do CPOD (aos 15 - 19 e 20 - 34 anos). Conclui-se que aspectos relacionados à localização e infraestrutura existente nas comunidades indígenas, que se vinculam à disponibilidade de serviços de saúde bucal, estão associados à ocorrência de cárie dentária em indígenas no Brasil.

Palavras-chave: Cárie dentária. Desigualdades em saúde. Doenças periodontais. Saúde bucal. Saúde de populações indígenas. Serviços de saúde bucal.

\section{Introduction}

From the arrival of the colonizers in the 18th century, the indigenous peoples of Brazil have gone through a process of population reduction caused by several factors, particularly, epidemics of infectious and parasitic diseases ${ }^{1}$. Currently, according to System of Information of the Attention to Indigenous Health (SIASI), the indigenous population living in hamlets in Brazil is about 670 thousand people, belonging to approximately 229 people that speak more than 170 languages. Since the 1980 s, a growth in population is evidenced in several ethnic groups. However, epidemiology and demographic information is still inadequate on the indigenous people of Brazil ${ }^{3}$. Data of official agencies and non-governmental organizations (NGOs) involved in indigenous health assistance indicate acute respiratory tract infections (ARTI) and diarrhea, apart from malnutrition, as the main determinants of mortality among the indigenous people ${ }^{1,4}$.

Despite less availability of data on the indigenous epidemiology profile, it is estimated that the mortality rates are up to four times higher than those found in the Brazilian population in general, highlighting a scene of health inequalities ${ }^{4}$. Lack of information on indigenous health also occurs in other regions of America ${ }^{5,6}$.

Several authors have raised the urgency of promoting researches on the oral health of the indigenous peoples in Brazil ${ }^{7,8}$. The information in this field is relevant for the knowledge of natural history of mouth diseases in these populations, as well as for the planning and implementation of adequate services of health to the local population ${ }^{9}$. According to data provided by the National Foundation of Health (FUNASA), the agency responsible for attention to indigenous health, the main problems of oral health in several ethnic groups are dental caries, periodontal disease and edentulism ${ }^{10}$.

A majority of researches on indigenous oral health in Brazil is composed by 
epidemiological studies involving samples not representative of ethnic transversal approaches ${ }^{11-13}$. The Xavante and several other ethnic people of Xingu Park are among the most investigated. In general, the studies indicate an increasing trend in the prevalence of caries through time. However, there are difficulties in establishing comparisons between the conditions of oral health of the different ethnic groups due to heterogeneity of the age groups investigated and in the methodological approaches ${ }^{14-16}$.

According to Arantes et al. ${ }^{17}$, the epidemiological profile of indigenous oral health in Brazil is complex and heterogeneous. There are groups with very high levels of caries attack, as the Kinsedje and Ikpeng, at Xingu. Alternatively, other groups exist, as the Yanomami to the west of Amazônia, present low prevalence of caries, with a diet comprising lesser use of refined sugar and other industrialized foods.

In other regions of the world also, as in Brazil, an increase in caries rates and other mouth diseases in indigenous people ${ }^{18,19}$ has been observed. The occurrence of dental caries is related to socioeconomic, cultural and biological determinants, such as age, sex, existence of programs and strategies for the promotion of oral health and prevention of mouth diseases, changes in diet patterns with an increase in consumption of industrialized foods and foods rich in carbohydrates and discontinuity of health assistance $\mathrm{e}^{20-21}$.

Different studies have demonstrated the relation between social inequities and dental caries in Brazil ${ }^{22-23}$. An ecological study carried out in the municipalities of the southern region revealed a major percentage of tooth extractions in cities with higher levels of income, besides the association between less access to the public health services and the worst oral health conditions ${ }^{24}$. In another ecological study, the association between socialdemographic inequities and prevalence of caries was demonstrated, highlighting to a scene of social inequities in oral health ${ }^{25}$.
Patussi et al. ${ }^{26}$ investigated the association between social privation, income inequity, social cohesion and level of dental caries in students of Distrito Federal. The results of the analysis with multiple linear regressions showed that the coefficient of Gini, used as indicative of social inequities, presented negative association with the percentage of the students without caries $(p=0.003)$ and positive association with an average of CPOD $(p=0.01)$.

According to Whitehead ${ }^{27}$, health inequity is systematic between socioeconomic groups in districts, and since it is being socially determined, it is unfair and can be avoided. Several researches have evidenced the probable existence of social inequities in the access and use of health services in Brazil ${ }^{28-29}$.

An objective of this study was to compare the epidemiological profiles with dental caries and to test the association between the average CPOD and the socio-environmental characteristics of indigenous populations in Brazil. It is an investigation of ecological character based on the analysis of published information in scientific literature.

\section{Materials and Methods}

Research of ecological character was carried out from the information published in epidemiological studies on dental caries in indigenous populations in Brazil. Ethnic groups for whom it was possible to locate results on the situation of dental caries, information was searched on the indigenous hamlets from the System of Information of Basic Sanitation for Indigenous Population $(\mathrm{SISABI})^{30}$.

The changeable reply used in this study was the index of caries attack (CPOD), calculated by the reason between the addition of dental caries elements lost and restored and the number of examined individuals. The average of CPOD of the studied populations was obtained from works identified in the LILACS, SciELO, Medline, SCOPUS and ISI Web of Science 
databases. The following keywords were used: (oral health AND indigenous) OR (oral health AND South American Indians) OR (oral health AND Indians) OR (oral health AND Brazilian Indians). The period of search was from 2000 to 2007, considering the analysis of only those works whose methodology indicated that the collection of oral health data happened from 2000. This period of search was chosen because it corresponds to the availability of SISABI data.

Nineteen works, identified through the procedures described above, were distributed in the following formats: two monographs of specialization, 11 dissertations of master, one $\mathrm{PhD}$ thesis, four periodic articles, and one book. These 19 works presented results of 25 different inquiries on the conditions of oral health of 48 indigenous ethnics in Brazil.

The variable referring to the socioenvironmental characteristics was obtained from the SISABI ${ }^{30}$, implanted by FUNASA at the beginning of 2000, continuing up to 2007. In this system, information on the sanitary conditions of the hamlets is collected, including physical structure of the houses, hygiene practices, raise animals, communication system and environmental characteristics. Such information aims at subsidizing the sanitation works in indigenous areas monitoring. For the purposes of present study, seven variable predictors related to the hamlets were selected: (a) localization (urban or agricultural zone); (b) availability of communication means, evaluated by the existence of radio and/or telephone; (c) existence of a junior high school in the community; (d) electrification existence (presence of electricity net); (e) types of floors in the houses (percentile of houses with wood or earthen floor); (f) types of roofs in the houses (percentile of houses with straw or sapê roof); (g) localization region (Legal Amazon or others). Legal Amazon includes states located in the northern region, besides the west of Maranhão and Mato Grosso states.

\section{Analysis of data}

Initially, the averages and standard deviation of CPOD were calculated in accordance with each variable predictor for each one of the selected age groups. The age groups for the diverse identified studies were derived based on the standards used in technical manuals for epidemiological surveys in oral health of the Ministry of Health (Ministério da Saúde - MS) $)^{31}$, which are: 12 years (children); from 15 to 19 years (youngs); from 20 to 34 years and from 35 to 44 years (adults); and 65 years or more (aged).

The associations between independent variables and the averages of CPOD for each age group were tested by analysis of simple and multiple linear regressions. The explainable variables that did not present multicollinearity, evaluated by VIF test (Variance Inflation Factor) with a cut-off equal to ten, were introduced in the model and selected by the Backward method to prevent suppression confuse ${ }^{32}$. The following variables have presented multicollinearity: the variable, type of floor of the house, to the 12 year old; the variable, type of roof of the house, to the 15 - 19 year old; the variable, place of housing and type of floor of the house, to the 20 - 34 year old.

Because of the use of Backward method, the effect (coefficient) of each covariate was controlled by the presence of other variables. In the final phase, the normality of the residues and absence of heterocedasticity was verified. The normality of the residues was verified by means of the Shapiro Wilk test $(p>0.05)$ in each selected age group and the assumption of heterocedasticity breaking was analyzed with adjusted values graphs and standardized residues.

The level of significance statistics established in all the analyses was 5\%. The data were analyzed with Software SPSS 17.0.

\section{Results}

A majority of the studies was carried out in indigenous hamlets located in Legal 
Amazon (88\%), in agricultural areas (96\%), areas with electricity (64\%), with junior high schools $(60 \%)$ and with radio or telephone availability (88\%).

Regarding to the methodologies used, 24 (96\%) were transversal and only $1(4 \%)$ was longitudinal ${ }^{20}$. The samples were inferior than 300 individuals in $52.6 \%$ of the studies. About 9074 individuals of 48 ethnic groups were examined, averaging $15 \%$ of the target population (60.322) under analysis in the 19 researches. The studies were conducted between 2000 and 2007, with the most part being carried out in the northern $(42.1 \%)$ and mid-western $(21.1 \%)$ regions. In the other regions, the frequencies were as follows: $15.8 \%$ in the southeast, $15.8 \%$ in the northeast and $5.3 \%$ in the south.

As indicated in Table 1, from the set of 19 studies, it was possible to analyze the distribution of CPOD and its components (dental caries, tooth lost and restored) in 12, stratified according to the age group and region of accomplishment (at Legal Amazon or otherwise). The findings in the age index of 12 years old demonstrated higher values of CPOD averages in ethnic groups located in Legal Amazon. Between the ethnic groups with lesser values in this age group, it is observed that the Kaiabi people from Xingu, presented CPOD of 3.0, whereas the Guarani from the state of Rio de Janeiro presented a value of 1.7. In the age group of 15 to 19 years old, again higher averages were found in the ethnic groups whose lands are in Legal Amazon, with prominence among the Kaiapó/MT $(\mathrm{CPOD}=13.1)$. Between 20 and 34 years old, there is similarity in the values found in the Kaiapó (16.5) and Tremembé (16.6), Ceará. In a general way, the results indicate higher average of CPOD in the ethnic groups that live in Legal Amazon.

In a comparative analysis of the contribution percentages of each component of the CPOD (Table 1) in Tukano, the largest values in the sum of dental caries and lost $(\mathrm{C}+\mathrm{P})$ in the age group of 12 years old (97.2\%) and 15 to 19 years old (97.8\%) were observed. Between 20 and 34 years old, the sum of these components was larger among the Guarani from São Paulo (100\%). In relation to the component $\mathrm{R}$ (restored), ethnic groups that presented higher values were the Kinsedje ( 12 years old $=72 \% ; 15$ to 19 years old $=82.4 \%)$ and the Kaiabi ( 20 to 34 years old $=61.5 \%$ ).

The averages of the CPOD index for each age group, in accordance with the independent variable, are presented in Table 2. The CPOD index varied between 4.9 for the 12 years old and 25.7 for majors or for those equal to 65 years old. In relation to the electrification variable, the CPOD averages were bigger in all the ages for the populations whose hamlets did not have availability of power. The means of communication variable presented different values between the youngest and the adults, with prominence for lesser index among the young from areas with radio or telephone.

For communities that had schools in the hamlets, the CPOD averages were higher between adolescents and adults, in general. With reference to the type of floor of the houses, the data are particularly limited. Analyses for children and adolescents indicated higher values in communities with bigger percentages of beaten earthen floor or wood. As for the type of roof of the habitations, the observed averages of CPOD demonstrate a possible protective effect in the groups with higher percentile of straw or sapê. Finally, when observing the variable region of localization of the indigenous hamlet, a higher average of CPOD was found in those situated at Legal Amazon.

Tables 3 to 5 present gross and adjusted associations between the independent variables and the averages of CPOD for the different age groups.

For the 12 years olds, only the region remained associated to the reduction in the average of the CPOD in the multivariate analysis $(\beta=-2.89, p=0.020)$. Indigenous 12 years old who lived in hamlets located outside Legal Amazon presented an average of 2.89 tooth loss with experience of caries in relation to those who live in hamlets in Legal Amazon (Table 3). 
Table 1 - Distribution of caries Index and its components in different indigenous populations, according to region, selected age groups, author and year of study, from 2000 to 2007.

Tabela 1 - Distribuição do Índice de cárie e seus componentes em diferentes populações indígenas, de acordo com a região, faixas etárias selecionadas, autor e ano de realização do estudo, 2000 a 2007.

\begin{tabular}{|c|c|c|c|c|c|c|c|c|c|c|c|c|c|c|}
\hline & \multicolumn{4}{|c|}{12 years old } & \multicolumn{4}{|c|}{15 to 19 years old } & \multicolumn{4}{|c|}{20 to 34 years old } \\
\hline Author/Year & Ethnic/State & $\mathrm{n}$ & DMFT(*) & $\begin{array}{c}C \\
(\%)\end{array}$ & $\begin{array}{c}\mathrm{L} \\
(\%)\end{array}$ & $\begin{array}{c}\mathrm{R} \\
(\%)\end{array}$ & $\operatorname{DMFT}(*)$ & $\begin{array}{c}C \\
(\%)\end{array}$ & $\begin{array}{c}\mathrm{L} \\
(\%)\end{array}$ & $\begin{array}{c}\mathrm{R} \\
(\%)\end{array}$ & $\mathrm{DMFT}\left({ }^{*}\right)$ & $\begin{array}{c}C \\
(\%)\end{array}$ & $\begin{array}{c}\mathrm{L} \\
(\%)\end{array}$ & $\begin{array}{c}\mathrm{R} \\
(\%)\end{array}$ \\
\hline $\begin{array}{l}\text { igonatto et } \\
\text { l. }{ }^{12} / 2001\end{array}$ & $\begin{array}{l}\text { Xingu - } 4 \\
\text { etnias/MT }\end{array}$ & 288 & 5.9 & ND & ND & 12.6 & 9.1 & ND & ND & 40.2 & 13.3 & ND & ND & 24.5 \\
\hline Vunes ${ }^{33} / 2003$ & Tukano/AM & 240 & 6.2 & 68.7 & 28.5 & 2.8 & 9.7 & 45.2 & 52.7 & 2.2 & ND & ND & ND & ND \\
\hline _oureiro $^{34} / 2003$ & $\begin{array}{l}\text { Kaiapó/MT } \\
\text { Apiaka/MT }\end{array}$ & $\begin{array}{c}137 \\
73\end{array}$ & $\begin{array}{l}3.5 \\
3.7\end{array}$ & $\begin{array}{c}42.8 \\
57\end{array}$ & $\begin{array}{c}0 \\
43 \\
\end{array}$ & $\begin{array}{c}57.2 \\
0\end{array}$ & $\begin{array}{c}13.1 \\
6.4\end{array}$ & $\begin{array}{c}27 \\
46.9 \\
\end{array}$ & $\begin{array}{l}41.2 \\
53.1\end{array}$ & $\begin{array}{c}31.8 \\
0\end{array}$ & $\begin{array}{l}16.5 \\
13.2 \\
\end{array}$ & $\begin{array}{l}22.7 \\
15.1\end{array}$ & $\begin{array}{c}50.5 \\
84\end{array}$ & $\begin{array}{c}26.8 \\
4.9\end{array}$ \\
\hline rantes $\mathrm{s}^{20} / 2004$ & Xavante/MT & 691 & 4.1 & 77.8 & 7.6 & 14.6 & 5.7 & 60.5 & 22.8 & 16.7 & 12.3 & 47.6 & 39.4 & 13 \\
\hline etogni ${ }^{35} / 2005$ & $\begin{array}{c}\text { Enawenê-nawê/ } \\
\text { MT }\end{array}$ & 253 & 4.1 & 44.2 & 4.6 & 51.2 & 7.9 & 43.8 & 23.2 & 43 & ND & ND & ND & ND \\
\hline arneiro $36 / 2005$ & Baniwa/AM & 59 & 6 & 48.6 & 26.2 & 25.2 & 8.2 & 24.5 & 47.5 & 28 & 13.8 & 27.5 & 65.9 & 5.8 \\
\hline Pacagnela $37 / 2006$ & $\begin{array}{c}\text { kinsed } \\
\text { kaiab } \\
\text { yudja } \\
\text { ikpen }\end{array}$ & $\begin{array}{l}201 \\
144 \\
144 \\
246 \\
\end{array}$ & $\begin{array}{c}5 \\
3.6 \\
3 \\
4.2 \\
\end{array}$ & $\begin{array}{c}24 \\
44 \\
30 \\
38.1 \\
\end{array}$ & $\begin{array}{c}4 \\
5.6 \\
0 \\
26.2 \\
\end{array}$ & $\begin{array}{c}72 \\
50 \\
70 \\
35.7 \\
\end{array}$ & $\begin{array}{l}6.8 \\
3.8 \\
8.4 \\
9.3 \\
\end{array}$ & $\begin{array}{c}8.8 \\
13.2 \\
19 \\
11.8 \\
\end{array}$ & $\begin{array}{c}8.8 \\
7.9 \\
7 \\
28 \\
\end{array}$ & $\begin{array}{c}82.4 \\
78.9 \\
75 \\
60.2 \\
\end{array}$ & $\begin{array}{c}11.7 \\
8.5 \\
13.6 \\
14.3 \\
\end{array}$ & $\begin{array}{c}5.1 \\
8 \\
7.4 \\
9.1 \\
\end{array}$ & $\begin{array}{c}33.3 \\
31 \\
31.1 \\
43.4 \\
\end{array}$ & $\begin{array}{l}60.7 \\
60.9 \\
61.5 \\
46.9 \\
\end{array}$ \\
\hline$/ 2003$ & Waj & 211 & 2.8 & ND & ND & ND & ND & ND & ND & $\mathrm{ND}$ & 11.1 & $\mathrm{ND}$ & ND & ND \\
\hline $8 / 2003$ & Xerente/TO & 41 & 4.6 & ND & ND & ND & ND & ND & ND & ND & ND & ND & ND & ND \\
\hline Soares- ${ }^{49} / 2004$ & 23 etnais/AM & 1523 & 5.4 & ND & ND & ND & ND & ND & ND & ND & ND & ND & ND & ND \\
\hline acagnela $37 / 2001$ & $\begin{array}{c}\text { kinsedje/MT } \\
\text { kaiabi/MT } \\
\text { yudja/MT } \\
\text { ikpeng/MT }\end{array}$ & $\begin{array}{l}- \\
- \\
- \\
-\end{array}$ & $\begin{array}{c}5.6 \\
3.8 \\
9.7 \\
10.8 \\
\end{array}$ & $\begin{array}{l}\text { ND } \\
\text { ND } \\
\text { ND } \\
\text { ND }\end{array}$ & $\begin{array}{l}\text { ND } \\
\text { ND } \\
\text { ND } \\
\text { ND }\end{array}$ & $\begin{array}{l}\mathrm{ND} \\
\mathrm{ND} \\
\mathrm{ND} \\
\mathrm{ND}\end{array}$ & $\begin{array}{c}8 \\
5.1 \\
12 \\
10.6 \\
\end{array}$ & $\begin{array}{l}\text { ND } \\
\text { ND } \\
\text { ND } \\
\text { ND }\end{array}$ & $\begin{array}{l}\text { ND } \\
\text { ND } \\
\text { ND } \\
\text { ND } \\
\end{array}$ & $\begin{array}{l}\text { ND } \\
\text { ND } \\
\text { ND } \\
\text { ND }\end{array}$ & $\begin{array}{c}17 \\
14.3 \\
17.8 \\
16.7 \\
\end{array}$ & $\begin{array}{l}\text { ND } \\
\text { ND } \\
\text { ND } \\
\text { ND }\end{array}$ & $\begin{array}{l}\text { ND } \\
\text { ND } \\
N D \\
\text { ND }\end{array}$ & $\begin{array}{l}\text { ND } \\
\text { ND } \\
\text { ND } \\
\text { ND }\end{array}$ \\
\hline Pereira- ${ }^{50} / 2007$ & Yanom & 367 & 2.3 & ND & ND & ND & 2.5 & ND & ND & ND & ND & ND & ND & ND \\
\hline Ereitas ${ }^{51} / 2008$ & Yanomami/AM & 823 & 0.5 & ND & ND & ND & 0.3 & ND & ND & ND & 0.3 & ND & ND & ND \\
\hline$u+r$ & & & & & & & & & & & & & & \\
\hline $3 / 2000$ & & & & 86.9 & 2.2 & 10.9 & 5.8 & 84 & 4.2 & 11.8 & 9.7 & 83.6 & 16.4 & 0 \\
\hline Piuvezam ${ }^{38} / 2005$ & Tremembé/CE & 102 & ND & ND & ND & ND & ND & ND & ND & ND & 16.6 & 54.2 & 39.1 & 6.7 \\
\hline $\begin{array}{l}\text { Sampaio et } \\
\text { al. }{ }^{39} / 2007\end{array}$ & Potiguara /PB & 1461 & 3.7 & 70.3 & 10.8 & 8.9 & 7.1 & 49.3 & 19.7 & 31 & ND & ND & ND & ND \\
\hline Alves Filho ${ }^{40} / 200$ & ICS & 111 & N & 55.2 & 11.9 & 32.8 & 2.8 & 46.1 & 17.5 & 34.5 & 5.3 & 28.8 & 32.7 & 37.2 \\
\hline Moura $^{41} / 2007$ & Guarani / SC & 141 & ND & ND & ND & ND & s & 38 & 12 & 50 & 8.9 & 56 & 17 & 27 \\
\hline $\begin{array}{l}\text { Diab e } \\
\text { Lucas }^{52} / 2008\end{array}$ & Xacriaba/MG & 158 & 3 & ND & ND & ND & ND & ND & ND & ND & ND & ND & ND & ND \\
\hline uimarães ${ }^{53} / 2000$ & ulniô/PE & 638 & 2.1 & ND & ND & ND & 5.4 & ND & ND & ND & 9.4 & ND & ND & ND \\
\hline
\end{tabular}

Notes: $\left({ }^{*}\right)$ mean DMFT values are relativized (\%) into its components: C (caries); L (lost) and R (restored)

ND: values not available. n: number of individuals in the sample

Notas: (*) os valores do CPOD médio encontram-se relativizados (\%) em seus componentes: $C$ (cariado); $P$ (perdido) e O (obturado).

ND: valores não disponíveis. n: número de indivíduos na amostra

In Table 4 the gross and adjusted analyses between the explainable variable and the averages of CPOD for the age group 15 and 19 years old are presented. The adjusted analysis demonstrated an inverse relation between the CPOD average and the variable predictors region (if outside Legal Amazon) $(\beta=-6.07, \mathrm{p}<0.01)$ and electrification $(\beta=-1.50, \mathrm{p}=0.013)$, besides a direct relation to the school presence $(\beta=3.03$, $\mathrm{p}=0.012)$. The localization of the hamlets in Legal Amazon and lack of power had increased the averages of the CPOD between
6.1 and 1.5 teeth affected by caries, respectively, while the presence of schools in the hamlets resulted in an average increment of 3.0 teeth affected by caries.

It can be observed in Table 5 that the age group between 20 and 34 years has an inverse relation among the average of the CPOD and the presence of power $(\beta=-2,70$, $\mathrm{p}=0.003)$, presence of straw/sapê roof $(\beta=-0.08, p=0.011)$ and localization of the hamlet outside Legal Amazon $(\beta=-7.14$, $\mathrm{p}=0.008)$, besides a positive association with the presence of schools in indigenous 
Table 2 - Descriptive statistics of caries index according to independent variables for each age group among indigenous groups in Brazil, from 2000 to 2007.

Tabela 2 - Estatística descritiva do Índice de cárie segundo as variáveis independentes para. cada faixa etária entre grupos indígenas no Brasil, 2000 a 2007.

\begin{tabular}{|c|c|c|c|c|c|c|c|c|c|c|}
\hline \multirow{3}{*}{ Variable } & \multicolumn{10}{|c|}{ Age groups } \\
\hline & \multicolumn{2}{|c|}{12 years old } & \multicolumn{2}{|c|}{15 to 19 years old } & \multicolumn{2}{|c|}{20 to 34 years old } & \multicolumn{2}{|c|}{35 to 44 years old } & \multicolumn{2}{|c|}{$\geq 65$ years old } \\
\hline & $\mathrm{n}$ & Mean \pm SD & $\mathrm{n}$ & Mean \pm SD & $\mathrm{n}$ & Mean \pm SD & $n$ & Mean \pm SD & $\mathrm{n}$ & Mean \pm SD \\
\hline Total & 25 & $4.9 \pm 2.1$ & 22 & $8.0 \pm 2.9$ & 20 & $13.7 \pm 2.8$ & 21 & $18,5 \pm 3,5$ & 16 & $25.7 \pm 4.4$ \\
\hline \multicolumn{11}{|l|}{ Place of housing } \\
\hline Urban & 1 & $2.2 \pm 0$ & 1 & $5.8 \pm 0$ & 1 & $15.7 \pm 0$ & 1 & $18.2 \pm 0$ & 0 & - \\
\hline Rural & 24 & $5.0 \pm 2.1$ & 21 & $8.1 \pm 2.9$ & 19 & $13.6 \pm 2.8$ & 20 & $18.5 \pm 3.6$ & 16 & $25.6 \pm 4.3$ \\
\hline \multicolumn{11}{|l|}{ Power } \\
\hline With electricity & 16 & $4.3 \pm 1.9$ & 14 & $7.1 \pm 3.1$ & 15 & $13.3 \pm 3.0$ & 13 & $17.9 \pm 1.9$ & 11 & $25.2 \pm 4.7$ \\
\hline Without electricity & 9 & $5.9 \pm 2.1$ & 8 & $9.5 \pm 1.7$ & 5 & $14.8 \pm 1.7$ & 8 & $19.4 \pm 5.2$ & 5 & $26.9 \pm 3.5$ \\
\hline \multicolumn{11}{|l|}{ Means of communication } \\
\hline None & 3 & $5.9 \pm 0.42$ & 2 & $8.9 \pm 1.1$ & 0 & - & 2 & $16.2 \pm 0.4$ & 1 & $21.8 \pm 0$ \\
\hline Radio and/or telephone & 22 & $4.7 \pm 2.2$ & 20 & $7.9 \pm 3.0$ & 20 & $13.7 \pm 2.8$ & 19 & $18.7 \pm 3.6$ & 15 & $25.9 \pm 4.4$ \\
\hline \multicolumn{11}{|l|}{ School } \\
\hline With school & 15 & $4.6 \pm 1.9$ & 13 & $8.2 \pm 3.2$ & 9 & $14.2 \pm 2.8$ & 13 & $18.6 \pm 3.6$ & 9 & $25.2 \pm 4.4$ \\
\hline Without school & 10 & $5.2 \pm 2.3$ & 9 & $7.7 \pm 2.5$ & 11 & $13.1 \pm 2.7$ & 8 & $18.3 \pm 3.5$ & 7 & $26.3 \pm 4.6$ \\
\hline \multicolumn{11}{|l|}{ Floor (earth or wood) } \\
\hline$<50 \%$ & 1 & $2.2 \pm 0$ & 1 & $5.8 \pm 0$ & 1 & $15.7 \pm 0$ & 1 & $18.2 \pm 0$ & & - \\
\hline $50-75 \%$ & 2 & $3.5 \pm 0.8$ & 2 & $7.9 \pm 5.5$ & 0 & - & 1 & $28.6 \pm 0$ & 1 & $31.8 \pm 0$ \\
\hline$>75 \%$ & 22 & $5.1 \pm 2.1$ & 19 & $8.1 \pm 2.8$ & 19 & $13.6 \pm 2.8$ & 19 & $17.9 \pm 2.7$ & 15 & $25.3 \pm 4.2$ \\
\hline \multicolumn{11}{|l|}{ Roof (straw or sapé) } \\
\hline$<50 \%$ & 4 & $3.9 \pm 1.7$ & 4 & $7.8 \pm 3.6$ & 2 & $16.2 \pm 0.6$ & 4 & $20.2 \pm 5.6$ & 1 & $31.8 \pm 0$ \\
\hline $50-75 \%$ & 6 & $5.0 \pm 2.6$ & 4 & $11.1 \pm 2.0$ & 5 & $14.5 \pm 2.5$ & 5 & $17.4 \pm 2.1$ & 5 & $24.3 \pm 5.1$ \\
\hline$>75 \%$ & 15 & $5.1 \pm 2.0$ & 14 & $7.2 \pm 2.4$ & 13 & $13.0 \pm 2.8$ & 12 & $18.3 \pm 3.2$ & 10 & $25.8 \pm 3.8$ \\
\hline \multicolumn{11}{|l|}{ Region } \\
\hline Legal Amazon & 22 & $5.2 \pm 1.9$ & 19 & $8.6 \pm 2.6$ & 17 & $13.7 \pm 2.6$ & & $18.8 \pm 3.6$ & 15 & $25.8 \pm 4.5$ \\
\hline Other regions & 3 & $2.3 \pm 0.7$ & 3 & $4.2 \pm 1.5$ & 3 & $13.8 \pm 4.2$ & 3 & $16.6 \pm 2.3$ & 1 & $24.8 \pm 0$ \\
\hline
\end{tabular}

hamlets $(\beta=3.29, \mathrm{p}=0.025)$. Indigenous people from 20 to 34 years of age who live in hamlets in Legal Amazon without power, roof of straw or sapé and with school, presented increases in the averages of 2.7 ; $0.1 ; 7.1$; and 3.3 teeth affected by caries, respectively.

The gross and adjusted analyses between the independent variable and the averages of CPOD for the age group between 35 and 44 years did not present significance statistics. The same has occurred for the age group 65 years or more.

The sets of independent variables for each one of the three final models of multiple linear regressions are $17.9 \%$ (12 years old); $47.9 \%$ ( 15 to 19 year olds); $39 \%$ (20 to 34 years old) of the CPOD variation. 
Table 3 - Multiple linear regression analysis between medium caries Index and socio-environmental indicators on indigenous groups in the selected age group, 12 years, from 2000 to 2007.

Tabela 3 - Análise de regressão linear simples e múltipla entre Índice de cárie médio e indicadores socioambientais entre grupos indígenas selecionados na idade-índice de 12 anos, 2000 a 2007.

\begin{tabular}{lccc}
\hline Variable & Regression coefficient not adjusted & $\mathrm{p}$-value & $\mathrm{R}^{2}$ \\
\hline Simple linear regression & & & \\
Place of housing & $2.76(-1.56,7.08)$ & 0.200 & 0.070 \\
Power & $-0.53(-1.47,0.41)$ & 0.259 & 0.055 \\
Means of communication & $-1.16(-3.81,1.50)$ & 0.377 & 0.034 \\
School & $-0.60(-2.38,1.17)$ & 0.489 & 0.021 \\
\% Floor (earth or wood) & $0.07(-0.01,0.14)$ & 0.062 & 0.143 \\
\% Roof (straw or sapé) & $0.02(-0.01,0.05)$ & 0.095 & 0.116 \\
Region (outside the Legal AM) & $-2.90(-5.29,-0.50)$ & 0.020 & 0.179 \\
\hline Multiple linear regression & Adjusted coefficient & & $\mathrm{R}^{2}$ adjusted \\
\hline Backward method & & & \\
$\quad$ Region & $-2.89(-5.29,-0.49)$ & 0.020 & 0.179 \\
\hline
\end{tabular}

Table 4 - Multiple linear regression analysis between medium caries Index and socio-environmental indicators selected among indigenous groups in ages from 15 to 19 years, from 2000 to 2007.

Tabela 4 - Análise de regressão linear simples e múltipla entre Índice de cárie médio e indicadores socioambientais entre grupos indígenas selecionados na faixa etária de 15 a 19 anos, 2000 a 2007.

\begin{tabular}{lccc}
\hline Variable & Regression coefficient not adjusted & $\mathrm{p}$-value & $\mathrm{R}^{2}$ \\
\hline Simple linear regression & & & \\
Place of housing & $2.30(-3.86,8.47)$ & 0.445 & 0.030 \\
Power & $-0.68(-2.06,0.70)$ & 0.319 & 0.050 \\
Means of communication & $-1.05(-5.55,3.46)$ & 0.634 & 0.012 \\
School & $0.43(-2.21,3.08)$ & 0.736 & 0.006 \\
\% Floor (earth or wood) & $0.06(-0.04,0.16)$ & 0.216 & 0.143 \\
\% Roof (straw or sapé) & $0.01(-0.05,0.46)$ & 0.968 & 0.000 \\
Region & $-4.40(-7.60,-1.21)$ & 0.009 & 0.257 \\
\hline Multiple linear regression & Adjusted Coefficient & & $\mathrm{R}^{2}$ adjusted \\
\hline Backward method & & & \\
$\quad$ Region & $-6.07(-9.01,-3.13)$ & 0.000 & 0.479 \\
Power & $-1.50(-2.64,-0.36)$ & 0.013 & \\
School & $3.03(0.76,5.29)$ & 0.012 & \\
\hline
\end{tabular}

\section{Discussion}

When analyzing the trajectory of indigenous peoples' health in Brazil, an important growth in the number of research is perceived on the conditions of oral health in the last decades ${ }^{17,20,36,40}$. However, little is known about the epidemiological profile of dental caries in indigenous communities.
Where such difficulty would be noticed, several studies suggest the existence of inequities between the indigenous people and the society involved, with respect to the access and use of services of attention to oral health ${ }^{4,7,17}$.

The component "restored" reflects a differentiation with respect to access to services of odontological attention. 
Table 5 - Multiple linear regression analysis between medium caries Index and socio-environmental indicators selected among indigenous groups in age from 20 to 34 years, from 2000 to 2007.

Tabela 5 - Análise de regressão linear simples e múltipla entre Índice de cárie médio e indicadores socioambientais entre grupos indígenas selecionados na faixa etária de 20 a 34 anos, 2000 a 2007.

\begin{tabular}{lccc}
\hline Variable & Regression coefficient not adjusted & $\mathrm{p}$-value & $\mathrm{R}^{2}$ \\
\hline Simple linear regression & $-2.13(-8.14,3.89)$ & & \\
$\quad$ Place of housing & $-0.76(-2.28,0.75)$ & 0.467 & 0.030 \\
Power & & 0.306 & 0.058 \\
Means of communication & $1.03(-1.59,3.66)$ & & \\
$\quad$ School & $-0.27(-0.14,0.87)$ & 0.419 & 0.037 \\
\% Floor (earth or wood) & $-0.03(-0.07,0.02)$ & 0.623 & 0.014 \\
\% Roof (straw or sapé) & $-4.40(-7.60,-1.21)$ & 0.280 & 0.064 \\
Region & Adjusted coefficient & 0.009 & 0.257 \\
\hline Multiple linear regression & & $\mathrm{p}$ value & $\mathrm{R}^{2}$ adjusted \\
\hline Backward method & $-2.70(-4.36,-1.04)$ & & \\
Power & $3.29(0.48,6.10)$ & 0.003 & 0.390 \\
School & $-0.08(-0.15,-0.02)$ & 0.025 & \\
Roof & $-7.14(-12.08,-2.19)$ & 0.011 & \\
Region & & 0.008 & \\
\hline
\end{tabular}

The percentage of restored teeth is indicative of the occurrence of a bigger or lesser degree of access to treatment. The "lost" component, in turn, reflects a mutilation practice, based on tooth extractions. Some data presented in this study (Table 1) suggest the existence of inequities of access in the regional scope. For example, it was observed in the Kinsedje people that $72 \%$ of elements were restored in 12 years old, whereas in the Apiaka, whose lands are located in the same Estado (MT), 43\% were extracted elements and no tooth was restored in this age.

With regard to caries occurrence, there are evidences that indicate an inverse epidemiological transition in the indigenous people. This is because there are cases of ethnic groups that are trying a gradual increase in the prevalence of caries throughout the years, in contrast with the national society. Research with the Xavante people ${ }^{17}$ demonstrates that a heterogeneous standard in the epidemiological profile of oral health in many communities of this ethnic group can be evidenced by inequities found in the prevalence of caries between the groups and their possible associations with the process of interaction with the national society, socio-cultural aspects and access to programs and health services. Another research with the Xavante ${ }^{42}$ indicates that one of the communities has presented reduction in the prevalence of dental caries after the implementation of a program promoting oral health at the beginning of the year, 2000. In the same study, a major incidence of caries in women between 20 and 24 years old was identified, with risk four times higher compared to men in the same age group. Arantes et al. ${ }^{42}$ argue that the differences found can be related to the inequities in access to information and health services influenced by the gender dimension.

With regard to the proposal of the present research, there are important limitations to the ecological approach in what concer to the possibility of control the effects of factors in a potential confuse. The intention was to explore with insights to assist in the production of new knowledge about inequities that exist in indigenous oral health. 
The results of multiple regressions carried out in this work provided evidences that suggest the association between socio-environmental inequities and the occurrence of dental caries in the indigenous population in Brazil. The findings indicate that worse conditions of oral health in indigenous communities exist among those who do not have access to electricity and live in areas in Legal Amazon, with roofs of the habitations of vegetal origin and with schools in indigenous hamlets.

Among 12 years old (Table 3 ) were observed lesser values of the CPOD averages in indigenous hamlets located outside Legal Amazon. This standard may result to the indigenous bigger difficulties in access to health care and to the actions of prevention and promotion in oral health, particularly in the indigenous hamlets more distant. Studies among the Baniwa ${ }^{36}$ and Xavante $^{17}$ people, found in the Amazonian west and east of Mato Grosso respectively, indicate great tooth loss among all age groups. This can be related to the difficulties of access and lack of health care coverage and discontinuity of assistance.

For the age groups between 15 and 19 years (Table 4), the results indicate an inverse or negative relation among the CPOD averages and the presence of electricity. In turn, there is also a direct relation between the indicated and an indigenous hamlet located in Legal Amazon. It is possible to notice, a direct relation between the index value and the presence of school in the indigenous hamlets, which can be regarded with the school meal ${ }^{43}$. Saliba et al. ${ }^{44}$, from a study carried out in schools of Araçatuba (SP), observed direct association between the school meal and prevalence of caries.

A positive association was detected between young adults (20 to 34 years old) in relation to the presence of schools in indigenous hamlets, as mentioned in the age group between 15 and 19 years, strengthening the condition of this variable as a predictor of risk to dental caries. The estimated coefficient (Table 5) that represents the difference in the index averages among the categories of this variable, indicates an increase of 3.29 in the CPOD average for indigenous hamlets with schools.

The positive relation between the presence of schools and CPOD, not only in the age group between 15 and 19 years but also in young adults (20 to 34 years old), must be seen with caution. The first point to be emphasized is that, in indigenous hamlets, it is not uncommon to observe adults in junior high schools, who also have access to the school meal. At the same time, it is possible that in indigenous hamlets where there is no school, people study in units located outside the indigenous lands. Thus, despite the school meal being a possible explanation to the positive relation between school and CPOD, there is an association that needs to be better investigated.

To be related to the variable in an added level, ecological studies present intrinsic limitations to the researches that use secondary sources, which indicate impracticability of quality control and consistency of data ${ }^{24}$. Despite recognizing these limitations, the present work looked to contribute to a bigger agreement concerning the epidemiological characteristics of dental caries in indigenous populations in Brazil. Though it is not possible to carry out causal inferences while this study has an exploratory character, the associations found deserve attention with reference to the identification of risk factors for caries in the indigenous people.

In the present time, epidemiological research on oral health suggests the association between bigger prevalence of caries and inequities of access ${ }^{45}$. Somewhat, the results of this research go in this direction, because they indicate that worse conditions of oral health exist in indigenous communities that do not make use of electricity and that live in certain regions of the country, such as the Amazon, for example. In this region, where the tooth averages with caries experience 
were bigger in almost all the analyzed age groups, the indigenous hamlets in general are more difficult to access. It is possible that the scene described by Carneiro ${ }^{36}$ for the Alto Rio Negro, in which the communities are visited by the health teams few times in a year, is also common for other areas of the Amazon.

One of the conjectures of an ecological study is the identification of a high variability of the exposition of interest between populations. Some of the biggest problems in using aggregate data is called cross reference and ecological fallacy ${ }^{46}$, because the correlation data represent the average levels of exposition, instead of degrees of exposition in individual level.

This work, as we know, is the first ecological study using data related to caries in indigenous populations carried out in
Brazil. It must be seen as a preliminary effort in the direction of advancing the understanding about determinant factors in the area of oral health. In the last years, there was an important growth in the studies on oral health of the indigenous people and it is expected that the accumulation of knowledge comes to subsidize the planning and implementation of initiatives in the healthcare.

\section{Acknowledgments}

We thank the Indigenous Assessorship Rio de Janeiro of the National Foundation of Health (FUNASA) - that offered access to SIASI and SISABI, fundamental to the achievement of the analyses carried out in this study.

\section{References}

1. Brasil. Fundação Nacional de Saúde - FUNASA. Política nacional de atenção à saúde dos povos indígenas. 2 ed. Brasília: Ministério da Saúde, 2002.

2. Brasil. Ministério da Saúde. Fundação Nacional de Saúde - FUNASA. Sistema de informação da atenção à saúde indígena (SIASI). Disponível em http://sis.funasa.gov.br/ siasi (Acessado em 08 de outubro de 2010).

3. Pagliaro H, Azevedo MM, Santos RV. Demografia e povos indígenas no Brasil. Rio de Janeiro: Fiocruz; 2005.

4. Santos RV, Coimbra Jr CEA. Cenários e tendências da saúde e da epidemiologia dos povos indígenas no Brasil. In: Coimbra Jr CEA, Santos RV, Escobar AL (orgs.). Epidemiologia e saúde dos povos indígenas do Brasil. Rio de Janeiro: FIOCRUZ; 2005. p. 13-47.

5. Coimbra Jr CEA, Santos RV. Emerging health needs and epidemiologic research in indigenous peoples in Brazil. In: FM Salzano, M Hurtado (eds.) Lost paradise and the ethics of research and publication. Oxford: Oxford University Press; 2004. p. 89-109.

6. Montenegro RA, Stephens C. Indigenous health in Latin America and Caribbean. Lancet 2006; 367: 1859-69.

7. Arantes R. Saúde Bucal dos Povos Indígenas no Brasil: Panorama atual e perspectivas. In: Coimbra Jr CEA, Santos $\mathrm{RV}$, Escobar Al (orgs.). Epidemiologia e saúde dos povos indígenas do Brasil. Rio de Janeiro: FIOCRUZ; 2005. p. 49-72.

8. Coimbra Jr CEA, Flowers NM, Salzano FM, Santos RV. The Xavantes in transition: health, ecology, bioanthropology in
Central Brazil. Michigan: University of Michigan, Human Enviroments Interactions Series; 2007.

9. Alves Filho P, Ribeiro NBC. Atenção à saúde bucal no programa de saúde indígena do Rio de Janeiro. In: Associação Brasileira de Odontologia do Rio de Janeiro, (org.). Novos rumos da saúde bucal: os caminhos da integralidade. Rio de Janeiro: ABORJ; 2005. p. 75-87.

10. Brasil. Fundação Nacional de Saúde. Diretrizes para a atenção à saúde bucal nos Distritos Sanitários Especiais Indígenas: manual técnico.Fundação Nacional de Saúde. Brasília: FUNASA; 2007.

11. Pose SB. Avaliação das condições de saúde bucal dos índios Xavantes do Brasil Central [dissertação de mestrado]. Rio de Janeiro: Escola Nacional de Saúde Pública da Fundação Oswaldo Cruz; 1993.

12. Rigonatto DL, Antunes JL, Frazão P. Dental caries experience in indians of the upper Xingu, Brasil. Rev Inst Med Trop São Paulo 2001; 43: 93-8.

13. Fratucci MVB. Alguns aspectos das condições de Saúde Bucal de uma população indígena Guarani M’bya no Município de São Paulo [dissertação de mestrado]. São Paulo: Faculdade de Saúde Pública da USP; 2000.

14. Tumang AJ, Piedade FF. Cárie dental, doenças periodontais e higiene oral em indígenas brasileiros. Bol Oficina Sanit Panam 1968; 64: 103-109.

15. Hirata J, Bergamaschi O, Oliveira A, Lázaro A, Martins C, Bosco L, Ando T. Estudo de prevalência de cárie em crianças 
indígenas no Parque Nacional do Xingu. Rev Odontol Univ São Paulo 1977; 15: 189-98.

16. Niswander JD. Further studies on Xavantes indians. VII the oral status of the Xavantes of Simões Lopes. Am J Hum Genet 1967; 19(4): 533-43.

17. Arantes R, Santos RV, Frazão P. Diferenciais de cárie dentária entre os índios Xavante de Mato Grosso, Brasil. Rev Bras Epidemiol 2010; 13(2): 223-36.

18. Jamieson LM, Armfield JM, Roberts-Thomson KF. Oral health inequalities among indigenous and nonindigenous children in the Northern Territory of Australia. Community Dent Oral Epidemiol. 2006; 34(4):267-76.

19. Nash DA, Nagel RJ. Confronting oral health disparities among American Indian/Alaska Native children: the pediatric oral health therapist. Am J Public Health 2005; 95(8): 1325-9.

20. Arantes R. saúde bucal dos povos indígenas no Brasil e o caso dos Xavantes de Mato Grosso. [tese de doutorado]. Rio de Janeiro: Escola Nacional de Saúde Pública da Fundação Oswaldo Cruz; 2005.

21. Arantes R, Santos RV, Frazão P, Coimbra Jr CEA . Caries, gender and socio-economic change in the Xavante Indians from Central Brazil. Ann of Hum Biol 2009; 36(2):162-75.

22. Moysés SJ. Desigualdades em saúde bucal e desenvolvimento humano: um ensaio em preto, branco e alguns tons de cinza. Rev Bras Odontol Saúde Coletiva 2001; 1(1): 7-17.

23. Peres KG, Bastos JRM, Latorre MRDO. Severidade de cárie em crianças e relação com aspectos sociais e comportamentais. Rev Saúde Pública 2000; 34(4): 402-8.

24. Fischer TK, Peres KG, Kupek E, Peres MA. Indicadores de atenção básica em saúde bucal: associação com as condições socioeconômicas, provisão de serviços, fluoretação de águas e a estratégia de saúde da família no Sul do Brasil. Rev Bras Epidemiol 2010; 13(1): 126-38.

25. Antunes JL, Narvai PC, Nugent ZJ. Measuring inequalities in the distribution of dental caries. Community Dent Oral Epidemiol 2004; 32(1): 41-8.

26. Pattussi MP, Marcenes W, Croucher r, Sheiham A. Social deprivation, income inequality, social cohesion and dental caries in Brazilian school children. Soc Sci Med 2001; 53(7): 915-25.

27. Whitehead M. A typology of actions to tackle social inequalities in health. J Epidemiol Community Health 2007; 61(6): 473-8.

28. Fernandes LS, Peres MA. Associação entre atenção básica em saúde bucal e indicadores socioeconômicos municipais. Rev Saúde Pública 2005; 39(6): 930-6.

29. Junqueira SR, Araújo ME, Antunes JLF, Narvai PC. Indicadores socioeconômicos e recursos odontológicos em municípios do Estado de São Paulo, Brasil, no final do século XX. Epidemiol Serv Saúde 2006; 15(4): 41-53.
30. Ministério da Saúde. Fundação Nacional de Saúde. Sistema de Informação de Saneamento Básico para as Populações Indígenas (SISABI). Disponível em http://sis.funasa.gov.br/ siasi (Acessado em 10 de junho de 2010).

31. Brasil. Ministério da Saúde. Secretaria de Políticas de Saúde. Departamento de Atenção Básica. Área Técnica de Saúde Bucal. Projeto SB2000: Condições de saúde bucal da população brasileira no ano 2000. Manual do coordenador. 2001.

32. Luiz RR, Costa AJL, Nadanovsky P. Epidemiologia e Bioestatística em Odontologia. São Paulo: Atheneu; 2008.

33. Nunes SAC. Avanços e desafios na implantação da atenção básica em saúde bucal dos povos indígenas nos rios Tiquié e Uaupés - Distrito Sanitário Especial Indígena - Alto Rio Negro - AM: análise de uma experiência [dissertação de mestrado]. Bauru: Faculdade de Ontologia de Bauru, USP; 2003.

34. Loureiro RW. Identificação de lesões pigmentadas dentárias nos índios kaiapó e apiaká do Mato Grosso [monografia]. Brasília: Universidade de Brasília; 2004.

35. Detogni AM. Práticas e perfil em saúde bucal: o caso Enawene-Nawe, MT, no período 1995-2005. [dissertação de mestrado]. Cuiabá: Instituto de Saúde Coletiva da UFMT; 2007.

36. Carneiro MCG. Um olhar sobre os índios Baniwa: saúde bucal e atenção odontológica na região do Alto Rio Negro, Amazônia Brasileira, 2000 a 2004 [dissertação de mestrado]. Rio de Janeiro: Escola Nacional de Saúde Pública, Fundação Oswaldo Cruz; 2005.

37. Pacagnella RC. Perfil Epidemiológico de Saúde Bucal da População do Parque Indígena do Xingu, entre os anos de 2001 e 2006. [dissertação de mestrado]. Ribeirão Preto: Faculdade de Medicina de Ribeirão Preto, USP; 2007.

38. Piuvezam G, Alves MSCF, Roncalli AG, Werner CWA, Ferreira AA. Oral health promotion: a study with the Tremembé indian community, CE. ROBRAC 2005; 14(37): 60-64.

39. Sampaio FC, Freitas CHSM, Cabral MBF, Machado ATAB. Dental caries and treatment needs among indigenous people of the Potiguara Indian reservation in Brazil. Rev Panam Salud Publica 2010; 27(4): 246-51.

40. Alves Filho P, Santos RV, Vettore MV. A Saúde Bucal dos índios Guarani no Estado do Rio de Janeiro, Brasil. Cad Saúde Pública 2009; 25(1): 37-46.

41. Moura PG. População indígena: condição bucal e estado nutricional materno infantil. [dissertação de mestrado]. Florianópolis: Universidade Federal de Santa Catarina; 2007.

42. Arantes R, Santos RV, Frazão P. Oral health in transition: the case of Indigenous peoples from Brazil. Int Dent J 2010; 60(3 Suppl 2): 235-40.

43. Ferreira AA. Estado nutricional e fatores associados ao crescimento de crianças indígenas Xavante, Mato Grosso [dissertação de mestrado]. Rio de Janeiro: Escola Nacional de Saúde Pública, Fundação Oswaldo Cruz; 2009. 
44. Saliba NA, Moimaz SAS, Mendes APR, Ferreira NF. A dieta escolar e a prevenção da cárie dentária nas escolas públicas. Rev Odontol Araçatuba 2003; 24(2):17-22.

45. Baldani MH, Almeida ES, Antunes JLF. Eqüidade e provisão de serviços públicos odontológicos no estado do Paraná. Rev. Saúde Pública. 2009; 43(3): 446-454.

46. Szklo M, Javier Nieto F. Epidemiology: beyond the basics. Massachusets: Jones and Bartlett Publishers; 2007.

47. Souza TAC. Etnografia Wajãpi/AP do processo saúdedoença: um enfoque odontológico [dissertação de mestrado]. Belo Horizonte : UFMG; 2005.

48. Seixas F. A mudança de hábitos alimentares e o aumento do CPOD na população indígena Xerente [monografia]. Brasília: Universidade de Brasília; 2003.

49. Soares OE (org.). Ações em saúde indígena amazônica: o modelo do Alto Rio Negro. São Gabriel da Cachoeira - AM: Federação das Organizações Indígenas do Rio Negro FOIRN; 2006.
50. Pereira SMC. Estudo epidemiológico em saúde bucal em uma comunidade Yanomami do Amazonas [dissertação de mestrado]. Manaus: UFAM; 2007.

51. Freitas LP. Saúde Bucal dos Yanomami da Região do Xitei e Ketaa - Roraima - Brasil [dissertação de mestrado multi-institucional]. Manaus: UFAM, FIOCRUZ, UFPA; 2008.

52. Diab AD, Lucas SD. Cárie dentária em crianças indígenas Xakriabá. Epidemiol Serv Saúde 2008; 17(2): 149-153.

53. Guimarães CD. Prevalência de cárie dentária e fatores de risco na comunidade indígena Fulni-ô - Pernambuco [dissertação de mestrado]. Camaragibe: Faculdade de Odontologia de Pernambuco, Universidade de Pernambuco; 2000 .

Received on: $05 / 19 / 11$

Final version presented: 08/29/11

Accepted on: 12/14/11 